\title{
EFFICIENCY OF CERTAIN PESTICIDES ON SOME BIOLOGICAL ASPECTS OF SPODOPTERA LITTORALIS (BIOSD) UNDER FILED AND LABORATORY CONDITIONS
}

\author{
Rehab E. M. E. Salem and M. A. Hendawy \\ Plant Protection Dept., Faculty of Agric., Zagazig Univ., Egypt.
}

Received: Oct. 4, 2016

Accepted: Oct. 31, 2016

\begin{abstract}
Efficiency of four pesticides belonging to different groups of chemicals , namely : Chlorosan, Agrinate, Daizinone and Nasractine on some biological aspects of $2^{\text {nd }}$ and 4 th instar larvae of the cotton leaf worm S. littoralis (Boisd) under field and laboratory conditions were investigated. The LC50 and LC 90 values were calculated after 24,48 , and $72 h$. Posttreatment. The obtained results showed that a wide range of toxicity of the tested pesticides, however the insecticide Chlorosan proved itself to be the highest toxic compound to the treated larvae as LC50 and LC90 values after 72h. post - treatment recording $0.01,0.83$ ppm and 0.13 , $5.23 \mathrm{ppm}$ for $2^{\text {nd }}$ and $4^{\text {th }}$ instar larvae, respectively. On the other hand, the compound Diazinon exhibited the lowest toxicity to the tested larvae at the both levels of toxicity (LC50 and LC90 values after $72 \mathrm{~h}$. were $16.86,69.31 \mathrm{ppm}$ and $39.59,186.67 \mathrm{ppm})$ for $2^{\text {nd }}$ and $4^{\text {th }}$ instar larvae, respectively. The other tested pesticides occupied an intermediate position. The tested pesticides increased the larval, pupal duration and malformed pupae and decreased the percentage of pupation, adult emergence compared with control.
\end{abstract}

Key words : Efficiency, pesticides, biological aspects, Spodoptera littoralis

\section{INTRODUCTION}

The cotton leaf worm ,S. littoralis (Boisd) is one of the most important insect pest attacking field and vegetables crops such as cotton, corn , peanut, clover and various fruits in Africa, Asia and Europe (Smagghe and Degheele , 1997 ; EL - Aswad et al. ,2003 and Ragaei and Sabry ,2011). The cotton leaf worm is the destructive pest to about 112 host plants from different families in Egypt as well as in Mediterranean and middle East countries (Kandil et al. ,2003 ; EL-Sinary et al. ,2008 and EL-Zoghby et al. ,2011) . To control the attacks of this pest several types of pesticides have been used, including synthetic, pyrethroids, organophosphates and steroidal compounds (Casida et al. 1988). The intensive use of conventional pesticides caused some side effects such as pest resurgence, pest resistance and outbreak of secondary pests (Davies et al., 2007; Mosallane et al., 2009 ). All pesticides cause serious toxicological problems to human and environment (Costa, et al. 2008 ; Relyea 2009). Pesticides cause decreased in larval and pupal weights, growth rate, fecundity level and larval and pupal duration (Marzouk et al. 2012).

Therefore, the present work aimed to study the efficiency of seven pesticides against the cotton leaf worm larvae. In addition the effects of tested pesticides on some biological and biochemical aspects of S. Littoralis under laboratory conditions.

\section{MATERIALS AND METHODS Tested insects:}

A laboratory strain of cotton leaf worm $S$. littoralis, was reared in the laboratory on castor bean leaves under constant laboratory conditions of $26+2 \mathrm{C}$ and 65_+5\%R.H.( EL-Defrawi et al.,1964) .The culture of the cotton leaf worm was initiated from freshly collected egg masses supplied from the division of cotton leaf worm, at plant protection research institute ,Dokki, Egypt. 
Tested insecticides :

\begin{tabular}{|l|l|l|l|}
\hline Trade name & Common name & concentration & Production company \\
\hline Chlorosan $(48 \% \mathrm{EC})$ & chlorpyrifos & At Recommended rates & Kafer el zaiaat \\
\hline Agrinate $(90 \% \mathrm{SP})$ & methomyl & At Recommended rates & Riotaam company \\
\hline Diazinon $(60 \% \mathrm{EC})$ & diazinon & At Recommended rates & $\begin{array}{l}\text { Wnzho losheng } \\
\text { dongo china }\end{array}$ \\
\hline Nasractine $(1.8 \% \mathrm{EC})$ & abamectin & At Recommended rates & El nasr company \\
\hline
\end{tabular}

\section{Toxicological studies:}

The tested compound were belonged to different groups of chemicals to assess the insecticidal activity of the tested compound were prepared using the commercial formulations the leaf dipping technique was adopted according to Abo- EL-Ghar et al. (1994) where freshly castor bean leaves were dipped for 5 seconds in one of the prepared concentration pesticides ,the treated leaves were left to natural dryness under laboratory conditions before being introduced to $S$. littoralis larvae. Hundred larvae distributed in five replicates (20 larvae I replicate) were used for each concentrations .Also, larvae were fed on leaves immersed in only water as a control .Newly moulted $4^{\text {th }}$ larval instars were fed on the treated leaves in a glass jar covered with muslin.

The corrected mortality of larvae was carried out using Abbott's formula (Abbott , 1925). The LC50, LC90 and slope values of the tested compounds were calculated using Finney's equation (1971), through soft were computer program.

\section{Biological studies :}

Newly moulted $2^{\text {nd }}$ and $4^{\text {th }}$ larval instars were segregated from the stock colony in clean glass Petri dishes and starved for 24hrs (Nasr,1999). Five concentration of pesticides were used .The concentrations were prepared by dissolving the tested pesticides in distilled water to get the appropriate concentrations. Pieces of castor bean leaves were treated by the leafdipping technique in the different concentrations of the tested compound and left in the air for $1 \mathrm{~h}$ to insure that it is completely dry, and then introduced to larvae for feeding . Eighty of starved larvae, distributed in four replicates (20 larvae / replicate ) were used for each concentration and allowed to feed for $24 \mathrm{hrs}$ on treated castor bean leaves .Unconsumed food, dead larvae and feaces were removed daily before introducing fresh leaves. The same technique described above was used for control except that the larvae were allowed to feed on castor bean leaves that dipped only in distilled water .Daily inspections were carried out until emergence occurred and the number of individuals that managed to develop was recorded larval mortality, larval duration, pupation \% ,pupal duration and pupal malformation $\%$ were recorded.

\section{Statistical analysis of data :}

Data obtained were analyzed for the analysis of variance (ANOVA) to compare the treatments. The ANOVA performed for each sampling of each treatment (SAS Institute Inc. , 1998) and if any significance was found at a risk level of $5 \%$ or lower $(p<0.05)$.

\section{RESULTS AND DISCUSSION 1 - Toxicity of some pecticides against the $2^{\text {nd }}, 4^{\text {th }}$ instars larvae of spodoptera littoralis (Boisd) :}

The results presented in Table (1) show that the toxicity of four pesticides : (Chlorosan, Agrinate, Daizinone and Nasractine ) against the $2^{\text {nd }}$ larvae instars of $S$. littoralis at different exposure time .

Among the pesticides, Chlorosan was the most effective compound followed by Agrinate while Nasractine was the least effective one followed Diazinon after $24 \mathrm{hr}$, $48 \mathrm{hr}$ and $72 \mathrm{hrs}$ of exposure . 
Table (1): Toxicity of some tested pesticides against $2^{\text {nd }}$ larval instar of Spodoptera littoralis (Boisd) by leaf dipping technique at different exposure times .

\begin{tabular}{|l|c|c|c|c|}
\hline Insecticides & Time(hrs) & LC50 & LC90 & Slope values \\
\hline Chlorosan & 24 & 0.15 & 10.16 & 0.701 \\
& 48 & 0.02 & 1.29 & 0.7351 \\
& 72 & 0.01 & 0.83 & 0.725 \\
\hline Agrinate & 24 & 5.49 & 84.92 & 1.055 \\
& 48 & 1.98 & 33.07 & 1.048 \\
& 72 & 1.59 & 20.88 & 1.147 \\
\hline \multirow{2}{*}{ Nasractine } & 24 & 23.94 & 91.67 & 2.19 \\
& 48 & 17.37 & 87.14 & 1,82 \\
& 72 & 9.79 & 45.16 & 1.93 \\
\hline Diazinon & 24 & 35.11 & 187.36 & 1.76 \\
& 48 & 21.17 & 88.55 & 2.06 \\
& 72 & 16.86 & 69.31 & 2.087 \\
\hline
\end{tabular}

The results indicated that there was negative relationship between the time elapsed post treatment and LC50 values of all the tested pesticides .

The LC50 values were $0.15,5.49,23.94$ and $35.11 \mathrm{ppm}$ for Chlorosan, Agrinate, Nasractine and Diazinon after $24 \mathrm{hrs}$ of exposure. Increasing the period of exposure from 48 to $72 \mathrm{hrs}$ decreased the LC50 values to reach $0.01,1.59,9.79$ and 16.86 ppm after $72 \mathrm{hrs}$ for Chlorosan, Agrinate, Nasractine and Diazinon respectively.

Data in Table (2) showed that LC50 values of all the tested pesticides were 0.48 , $10.05,23.59$ and $52.11 \mathrm{ppm}$ for Chlorosan , Agrinate, Nasractine and Diazinon after $24 \mathrm{hrs}$ of exposure. Increasing the period of exposure from 48 to $72 \mathrm{hrs}$ decreased the LC50 values to reach $0.26,6.55,20.32$ and $46.68 \mathrm{ppm}$ at $48 \mathrm{hrs}$ and $0.13,5.39,16.44$ and $39.59 \mathrm{ppm}$ at 72 hours for Chlorosan , Agrinate , Nasractine and Diazinon, respectively .

Generally ,the $2^{\text {nd }}$ larval instar was found to be more sensitive to the tested compounds than $4^{\text {th }}$ instar. The obtained low values of slope function indicated the homogenous response of the treated larvae to different concentrations of the tested compounds. The above obtained results are in agreement with those obtained by (Badr,2000 ; Culter et al. 2005 and Han et al.2006).

The $4^{\text {th }}$ larval instar tolerance could be due to the changes in anatomy, physiology and size through which the compounds passes or may be due to difference in liability to toxicant penetration ( Busvine , 1971).

\section{2- Sub lethal effect of some pesticides on some biological aspects of Spodoptera littoralis :}

The main biological aspects of $S$. littoralis after feeding the $2^{\text {nd }}$ and $4^{\text {th }}$ instar larval for 24hours , 48 hours for tested insecticides on castor bean leaves treated were shown in Table $(3,4)$. 
Among the pesticides, Chlorosan was the most effective compound followed by Agrinate while Diazinon was the least effective one followed Nasractine after $24 \mathrm{hr}$, $48 \mathrm{hr}$ after treatment.

The mortality percentage of $2^{\text {nd }}$ instar larvae were $100,90,70,66,56,48 ; 96$ , $90,76,70,50,40 ; 50,64,58,44,22$, $24 ; 50,70,50,44,28$ and 22 after $1,3,5,7,11$ and 14 days for Chlorosan , Agrinate , Nasractine and Diazinon, respectively, after $24 \mathrm{hrs}$ post treatment under field condition, residual effects were $71.7,70.3,43.7$ and $44 \%$; while the mortality percentage of $4^{\text {th }}$ instar larvae were $84,80,62,60,40,40 ; 80,76,68,48$, 44,$38 ; 50,36,38,28,30,22 ; 44,50$, $36,36,18$ and 20 after $1,3,5,7,11$ and 14 days for Chlorosan, Agrinate, Nasractine and Diazinon, respectively, after $24 \mathrm{hrs}$ post treatment under field condition, residual effects were $61.6,59,34$ and $34 \%$.

The mortality percentage of $4^{\text {th }}$ instar larvae were 84 after one day to 40 after 14 days for Chlorosan ,80 to 38 for Agrinate , 44to 20 for nasractine and 50 to 22 for diazinon after $24 \mathrm{hrs}$ post treatment under field condition. Data shows that residual effect of Chlorosan was $72.8 \%$,Agrinate $69.5 \%$, Diazinon $42 \%$ and Nasractine 39\%

The mortality percentage of $2^{\text {nd }}$ instar larvae were $100,96,74,68,56,48$; $100,94,80,72,58,40 ; 60,64,60,44$, 28,30 and $64,72,56,44,40,24$ after 1,3,5,7,11 and 14 days for Chlorosan , Agrinate, Nasractine and Diazinon ,respectively, after $48 \mathrm{hrs}$ post treatment under field condition, residual effects were $73.7,74,47.7$ and $50 \%$; while the mortality percentage of $4^{\text {th }}$ instar larvae were $100,88,66,60,48,42 ; 88,80,72,66$, 44,$46 ; 58,44,38,32,32,24$ and 50 , $62,38,40,33$ and 28 after 1,3,5,7,11 and 14 days for Chlorosan, Agrinate, Nasractine and Diazinon, respectively, after48hrs post treatment under field condition, residual effects were $67.3,66$, 38 and $40 \%$.

Table (2): Toxicity of some tested pesticides agAnstacthe larval instars of Spodoptera littoralis (Boisd) technique by leaf dipping exposure times. different 72

\begin{tabular}{|c|c|c|c|}
\hline 72 & 5.39 & 43.69 & 1.41 \\
\hline 24 & 23.59 & 88.28 & 2.236 \\
\hline 48 & 20.32 & 67.67 & 2.45 \\
\hline 72 & 16.44 & 49.69 & 2.66 \\
\hline 2 Sllope valu & 52.11 & 258.40 & 1.84 \\
\hline & 46.68 & 240.62 & 1.79 \\
\hline $72^{0.925}$ & 39.59 & 186.67 & 1.90 \\
\hline
\end{tabular}

LC50 Diazihon LC90

c90

\begin{tabular}{l|l}
0.48 & 11.70 \\
0.26 &
\end{tabular}

\begin{tabular}{l|l}
41.70 & 72 \\
\hline 41 & 72 \\
\hline
\end{tabular}

\begin{tabular}{l|l}
0.26 & 8.4 \\
0.13 & 5.23
\end{tabular}

24

10.05

6.55

5.23

0.8009

1.309

1.323 


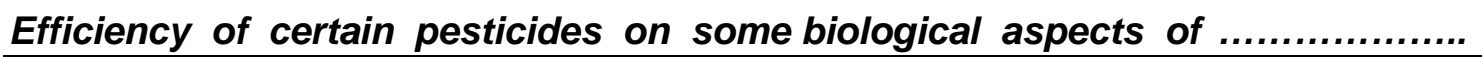

\begin{tabular}{|c|c|c|c|c|c|}
\hline \multirow{8}{*}{ 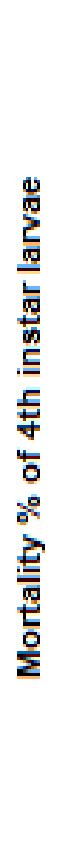 } & 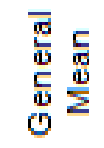 & $\stackrel{\infty}{\mathbb{N}}$ & \begin{tabular}{|l} 
டி \\
8 \\
0
\end{tabular} & F & ल \\
\hline & 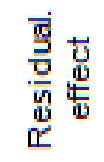 & $\stackrel{\varphi}{\dot{0}}$ & 욤 & ले & ले \\
\hline & $\stackrel{0}{\circ}$ & 웅 & ल & สี & 으 \\
\hline & $=0$ & 寸 & 守 & 요 & $\stackrel{\infty}{-}$ \\
\hline & $r i$ & 8 & 高 & $\stackrel{\sim}{\sim}$ & \% \\
\hline & ن & ชิ & 18 & ल & $\mathscr{m}$ \\
\hline & $m$ i & ○ & $\stackrel{\varphi}{R}$ & $\mathscr{m}$ & 8 \\
\hline & $-\frac{\mathrm{m}}{\mathrm{d}}$ & ষ & ○ & 80 & 寸 \\
\hline \multirow{8}{*}{ 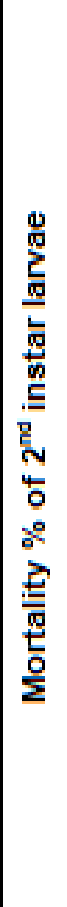 } & 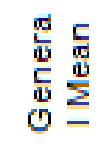 & $\begin{array}{l}\infty \\
\stackrel{\infty}{\infty} \\
\infty\end{array}$ & $\begin{array}{l}N \\
N \\
\infty\end{array}$ & $\begin{array}{l}\infty \\
\dot{\phi} \\
\dot{q}\end{array}$ & 年 \\
\hline & 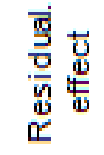 & $\frac{i}{r}$ & $\stackrel{m}{\stackrel{m}{R}}$ & r & 寸 \\
\hline & $\stackrel{0}{\circ}$ & $\stackrel{\infty}{q}$ & 웅 & d & N \\
\hline & $=0$ & $\mathscr{0}$ & 웅 & N & $\stackrel{\infty}{\sim}$ \\
\hline & $r \quad \dot{0}$ & 8 & 웅 & F & J \\
\hline & ن & R & $\mathscr{R}$ & 电 & 8 \\
\hline & $m$ i & 8. & 8) & ఫ్ & 웃 \\
\hline & - 突 & 움 & $\%$ & 8 & 8 \\
\hline \multicolumn{2}{|l|}{ 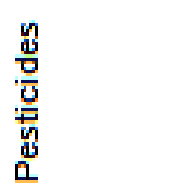 } & 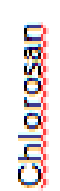 & $\begin{array}{l}\stackrel{4}{3} \\
3 \\
3 \\
0 \\
\end{array}$ & $\begin{array}{l}\frac{5}{3} \\
\frac{3}{3} \\
\frac{3}{0}\end{array}$ & 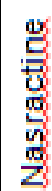 \\
\hline
\end{tabular}

\begin{tabular}{|c|c|c|c|c|c|}
\hline \multirow{8}{*}{ 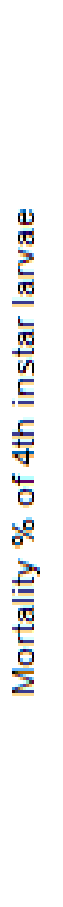 } & 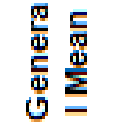 & חָ & $E$ & 孚 & 昌 \\
\hline & 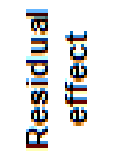 & ִֻ & 8 & m & 우 \\
\hline & $\stackrel{\nabla}{\square}$ & ข & $\mathscr{q}$ & d & $\stackrel{\sim}{\sim}$ \\
\hline & $=\dot{0}$ & $\stackrel{\infty}{q}$ & 寸 & लू & สี \\
\hline & $\sim \dot{0}$ & 8 & 8 & ले & 웅 \\
\hline & i & 8 & $\mathbb{N}$ & 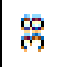 & 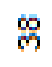 \\
\hline & $m$ r & $\stackrel{\infty}{\infty}$ & ○ & 夺 & ชิ \\
\hline & - 要 & 음 & $\infty$ & 兽 & 웅 \\
\hline \multirow{8}{*}{ 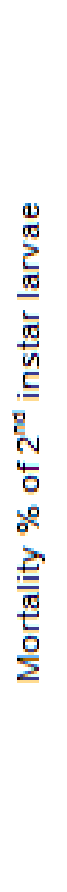 } & 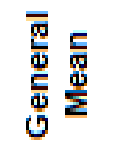 & $\begin{array}{l}\infty \\
\infty \\
\infty\end{array}$ & 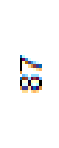 & 舟 & 5 \\
\hline & 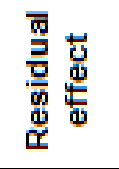 & $\hat{n}$ & $\stackrel{r}{r}$ & 年 & 웅 \\
\hline & $\stackrel{0}{\square}$ & 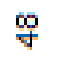 & 우 & 이 & $\stackrel{\sim}{N}$ \\
\hline & $=\dot{0}$ & $\mathscr{0}$ & 电 & $\stackrel{\sim}{\sim}$ & 우 \\
\hline & $\sim \dot{0}$ & 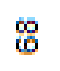 & $\mathbb{N}$ & g & 寸 \\
\hline & i & I & ஓ & 8 & 电 \\
\hline & $m$ i & $\mathscr{\%}$ & むా & ఫ్ & $\mathbb{N}$ \\
\hline & - 要 & 은 & 음 & 8 & ङै \\
\hline 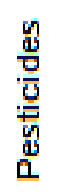 & & 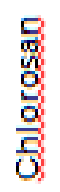 & $\begin{array}{l}\stackrel{4}{3} \\
\stackrel{3}{3} \\
\frac{9}{4}\end{array}$ & $\begin{array}{l}\frac{5}{8} \\
\frac{3}{1 / 2} \\
\frac{3}{2}\end{array}$ & 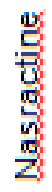 \\
\hline
\end{tabular}


Generally , Chlorosan induces the highest larval mortality followed by Agrinate , respectively. Mode of the mortality of larval from insecticides investigated that the nerve synapses of insects contain a chemical mediator known as Acetylcholine (Ach), through which nerve impulses transmits from one nerve axon to another. Acetylcholine esterase hydrolyzes Acetylcholine to prevent its accumulation at the nerve synapses since its accumulation leads to death as a result of disruption of nerve transmission .In insects, the mode of action of chlorosan which is toxic to insects by acting as nerve poison and killing insect by inhibition of acetylcholine esterase (Du Bois, 1961).

Pesticides efficiency in larval mortality reviewed by many authors ( Abdel - Fattah , 1970 ; EL- Sheakh , 1988 ; and Abd EL Kader et al., 1995 EL-Naggar et al. 2013)

All the tested pesticides resulted a significant increase in both larval and pupal durations as well as malformed pupae in compared to control were shown in Table (5). Also, these effects were more pronounced for Chlorosan, Agrinate than all tested pesticides.
The larval duration were $8.1,7.6,9.2$ and 9.1 days for Chlorosan, Agrinate , Diazinon and Nasractine, respectively, in compared with control (12.4 days), while pupal duration were $5.5,5.0,6.7$ and 8.0 days for the previous pesticides ,respectively in compared to the control (8.3 days). The percentage of malformed pupae ranged from $50 \%$ to $14 \%$ in compared to $3 \%$ for the control. On the other hand, the tested pesticides induced a significant suppression in pupation and adult emergence when compared with control . Also, there was insignificant difference between the effect of the tested pesticides with exception of Chlorosan effect on pupation as it induced the highest percentage $20 \%$. However, the pupation varied from $25 \%$ to $18 \%$ in compared to 97 $\%$ for the control. The adult emergence ranged from $79 \%$ to $50 \%$ in compared to 93 $\%$ for the control. However, the decrease in adult emergence could be due to the fact that the toxic blocks the maturation of imaginal discs which are primordial for many adult integument structure in endopetrygote insect (Schniederman 1972).

Table (5): Effect of some pesticides on some biological aspects of the cotton leaf worm Spedoptora littoralis

\begin{tabular}{|c|c|c|c|c|c|c|c|c|}
\hline Pesticides & $\begin{array}{c}\text { Mean } \\
\text { larval } \\
\text { weight } \\
\text { (g) }\end{array}$ & $\begin{array}{c}\text { Larval } \\
\text { duration } \\
\text { (days) }\end{array}$ & $\begin{array}{c}\text { Mean } \\
\text { pupal } \\
\text { weight } \\
\text { (g) }\end{array}$ & $\begin{array}{c}\text { Pupal } \\
\text { duration } \\
\text { (days) }\end{array}$ & $\begin{array}{c}\% \\
\text { pupation }\end{array}$ & $\begin{array}{c}\% \\
\text { malformed } \\
\text { pupae }\end{array}$ & $\begin{array}{c}\text { Adult } \\
\text { emergence }\end{array}$ & $\begin{array}{c}\text { Adult } \\
\text { longevity } \\
\text { (days) }\end{array}$ \\
\hline Chlorosan & $0.337 \mathrm{~d}$ & $8.167 \mathrm{~b}$ & $0.223 \mathrm{~b}$ & $5.500 \mathrm{a}$ & $20.000 \mathrm{e}$ & $44.333 \mathrm{a}$ & $50.000 \mathrm{~b}$ & $2.333 \mathrm{a}$ \\
\hline Agrinate & $0.387 \mathrm{~d}$ & $7.667 \mathrm{e}$ & $0.260 \mathrm{~b}$ & $5.000 \mathrm{a}$ & $18.000 \mathrm{e}$ & $50.000 \mathrm{a}$ & $58.667 \mathrm{~b}$ & $3.333 \mathrm{a}$ \\
\hline Diazinon & $0.527 \mathrm{~b}$ & $9.267 \mathrm{~b}$ & $0.373 \mathrm{a}$ & $6.733 \mathrm{a}$ & $38.667 \mathrm{~d}$ & $28.667 \mathrm{~b}$ & $79.333 \mathrm{a}$ & $4.000 \mathrm{a}$ \\
\hline Nasractine & $0.620 \mathrm{a}$ & $9.167 \mathrm{~b}$ & $0.360 \mathrm{a}$ & $8.000 \mathrm{a}$ & $25.333 \mathrm{e}$ & $14.000 \mathrm{e}$ & $74.000 \mathrm{a}$ & $5.500 \mathrm{a}$ \\
\hline Control & $0.660 \mathrm{a}$ & $12.433 \mathrm{a}$ & $0.423 \mathrm{a}$ & $8.300 \mathrm{a}$ & $97.000 \mathrm{a}$ & $3.667 \mathrm{c}$ & $93.333 \mathrm{a}$ & $8.033 \mathrm{a}$ \\
\hline F. test & $* *$ & $* *$ & $* *$ & $* *$ & $* *$ & $* *$ & $* *$ & $* *$ \\
\hline LSD & 0.052 & 1.81 & 0.053 & 1.341 & 8.532 & 7.623 & 10.5 & 1.5 \\
\hline
\end{tabular}

**significant at 0.01 . 
In general, it was observed that pesticide Chlorosan was more effective in all the mentioned measured parameters ,however, the reduction in the efficiency of converting ingested and digested food (Senthil Nathan et al. 2005) pupal mortalities in this study were obvious and recorded after treatment of both $2^{\text {nd }}$ and $4^{\text {th }}$ larval instars with the used, there were close dependent effect on pupation and pupal mortalities, the results are in harmony with the results obtained by ( Butter et al. 2003 ; Biddinger et al. 2006 ; Salokhe et al. 2008 and; EL- Khely et al. 2014). Total inhibition of adult emergence in the biological studies were recorded for the treated larvae with the used, it was obvious that the percents of inhibition were in positive relationship with the increase of concentrations these results are in agreement with those obtained by (Butter et al. 2003; Biddinger et al. 2006 ; Saloke et al. 2008 ; Wang - Tian. 2009 and EL- Sheikh et al. 2013)

\section{REFERENCES}

Abbott, W.S. (1925). A method of computing the effectiveness of an insecticide. J. Econ . Entomol. , 18 : $265-277$.

Abd EL - Fattah, M.S. (1970). The environmental toxicology of cotton leaf worm spodoptera littoralis (Boisd) . M.Sc. Thesis, Fac. Agric. , Ain Shams Univ. ,Cairo, Egypt.

Abd EL - Kader, M.M., M.N. Shaaban, H.A. Abd EL - Rahman, O.K. Moustafa and E.M. Radwan (1995). Effect of insect growth inhibitors insecticides and their combination on some biological aspects of spodoptera littoralis (Boisd). Egypt . J.Agric. Res. , 37 (3) : $677-685$.

Abo EL - Ghar, G.E.S., M.S. Halil and T.M. Erd. (1994). Effect of plant excrats on development and fecundity of Agroits ipilon .Bull. Ent. Soc. Egypt. Econ. Ser. ,21: $171-190$.

Busvine, J.R. (1971). Acritical review of technique for testing insecticides common wealth .Agric. Bureau, England, 345pp.

Badr, N.A. (2000). Efficacy of some natural products and insect growth regulators consult against the cotton leaf worm spodoptera littoralis (Bosid) . Egypt . J. Appl . Sci. , 15 (9) : 316 - 327.
Butter, N. S., S. Gurmeet and A. K. Dhawanm (2003). Laboratory evaluation of the insect growth regulator lufenuron against helicoverpa amigera on cotton . Phytopara sitica , 31(2) : 56-60.

Biddinger, D., L. Hull, H. Huang, B. Mcpheron and M. Loyer (2006). Sublethal effects of chronic exposure to tebufenozide on the development survival and reproduction of the tufted apple bud moth . J. Econ. Entomol . 44 (3) : 834- 842.

Casida, J.E. and G.B. Quistad (1998). Golden age of insecticides research: past, present, or future ? Anmu. Rev. Entoml. 43: 1-16.

Culter, G.C., Scott . C.D. Dupree, J.H. Tolman and C.R. Harris (2005). A cute and sublethal toxicity of novaluran, a novel chitin synthesis inhibitor to Leplinotarsa decembineata (Colea :Chrysomelidae ). Pest manag, Sci. , 61 (11) : 1060 - 1068.

Costa, L.G. and A. Vitalone (2008). Neurotoxicity of pesticides : A brief review . Forntiers Bio. Sci., 3: 1240 1249.

Du - Bois, K.P. (1961). Potentiation of the toxicity of organophosphorous compounds .Advances pest .Contr. Res., $4: 117-151$.

Davies, I.G.E., L.M. Field, P.N.R. Usherwood and M.S. Williamson (2007). Pyrethrins and insect sodium channels. IUBMB life 59: 151 - 162.

El - Aswad, A.F., S.A.M. Abdelgaleil and M. Nakatani (2003). Feeding deterrent and growth inhibitory properties of limonoids from Khaya senegalensis against the cotton leafworm spodoptera littoralis . Pest Mang. Sci. , 60 : $199-203$.

El - Defrawi, M.E., A. Tappozada, M. Mansour and M. Zaid (1964). Toxicological studies on the Egyptian cotton leafworm spodoptera littoralis L. Susceptibility of different larval instars of Prodenia littoral to insecticides. J.Econ. Ent. ,57:591 - 593 .

El -Khely, R.M.A., M.F. EL-Banley, EL-Tawil and W.L. Abouamer (2014). Effect of three plant extracts on some biological aspects of cotton leafworm spodoptera littoralis (Boisd) . Middle East journal of applid sciences 4(2):243 -251. 
EL - Naggar, Jehan, B.A. (2013). Sublethal effect of certain insecticides on biological and physiological aspects of spodoptera littoralis (Boisd) . Nature and Science . 11 (7) : 19-25.

El - Sinary, H. Nagllaa, A.T. Ashour and F.A. Megahed (2008). Water extracts from leaves of Morus alba varieties as botanical pesticides against the cotton leaf worm spodoptera littoralis (Boisd). Bull. Ent. Soc . Egypt, Econ. Ser. 34 : 69 $-79$.

El - Sheakh, A.A. (1988). Physiochemical effect of some organophosphorous insecticides on the cotton leaf worm spodoptera littoralis (Boisd) . PhD. Thesis, Fac. Agric ., Cairo Univ, Egypt.

El- Sheikh, T.A.A., Heba S. Rafea, A.M. ELAasar and S. H. Ali (2013). Biological and biochemical effects of Bacillus thuringiensis, Serratta marcescens and teflubenzuron on cotton leafworm . Egypt, J. Agric, Res. 91(4):1327-1345.

El - Zoghby, Fadia , A., M.H. Salem and G.G. Gadlhak (2011). Effects of Melilotus indiea crude extracts and cascade (IGR) spodoptera littoralis reproductive orgams. Bull. Ent.Soc. Egypt, Econ. Ser., $37: 121-136$.

Finney, D.J. (1971). Probit analysis a statistical treatment of the sigmoid response curve . 7th Ed. , Combridge .Univ. Press. Combridge . England.

Han, M., S. Kim and Y. Ahn (2006). Insecticidal and antifeedant activities of medicinal plant extracts against Attagenus unicolor Japonicus . J.Stored pord pesh. , 42 (1) : 15- 22.

Kandil, M.A., N.F. Abdel - Aziz and E.A. Sammour (2003). Comparative toxicity of chlofluazuron and leufenuron against cotton leaf worm spodoptera littoralis . Egypt. J. Agric . Res. NRC, 2 : 645-661.

Mosallane Jad, H. and G. Samgghe (2009). Biochemical mechanisms of methoxyfenzide resistance in the cotton leafworm spodoptera littoralis (Boisd) .Pest mange. Sci. 65: $732-736$.

Marzouk, E.A., M.M.M. Megahed, W.L. Abouamer and M.M. EL - Banby (2012). Effects of three pesticides on some biological aspects of cotton leafworm spodoptera littoralis (Boisd) larvae under laboratory conditions. J. plant prot. And path. , Mansoura Univ. , Vol. 3 (12) : $1345-1352$.

Nasr, F.N. (1999). New isolated Bacillus spp. against the cotton leaf worm spodoptera littoralis (Boisd) . Egypt .J. Agric. Res. 77 (4) : 1573 - 1583.

Relyea, R.A. (2009). A cocktail of contaminants how mixtures of pesticides at low concentration affect aquatic communities . Oecologia. 159, 363 376.

Ragiea, M. and K.H. Sabry (2011). Impact of spinosad and buprofezin alone and in combination against the cotton leaf worm spodoptera littoralis under laboratory conditions .J. of Bio - Pesticides , 4 (|2) : $156-160$.

Schneidermann, H.A. (1972). Insect hormone and insect control (in :insect Juvenile Hormone, Chemistry and Action , j.j. Menn and M. Beroza (EDS), Academic press, NewYork, London, 3:27 .

SAS Institute Inc., (1988). SAS procedures Guide , 6.03 Edition. SAS Institute Inc. , Cary, NC.

Smaggha, G., L. Audenaert and D. Degheele (1997). Tebufenozide is toxicity correlated with pharmacatineties and metabolism of different strains of the Egyptian cotton leafworm . Mededelingen - Faculteies - Landbouwkundige Toegepaste - Biologische Wetenschappen - Univ. - Gent. , 60 (3b) : 1015 - 1016.

Senthil - Nathan, S. and K. Kalaivanu (2005). Efficacy of nucleo polyhedral virus (NPV) and azadirachtin on Spodoptera litterials falricious (Lepidoptera :Noctudiae). Biol .Control, 43 :93- 98.

Shalokhe, S. G., J.K. Pal and S. N. Mukherjee (2008). Effect of sublethal contentrations of flufenox on development growth and reproductive performance of Tribolium castanellm .J of invertebrate reproductive development 43 (2) : 141 - 150.

Wang, J. and D. Tian (2009). Sublethal effects of Methoxyfenozide on .Cotton science, 21 (3) : $212-217$. 


\section{فعاليه بعض المبيدات على السمات البيولوجيه لاوده ورق القطن تحت الظروف المعملية والحقلية}

رحاب عيداروس محمد السيد سالم ، محمد عبد العال هنداوي قسم وقايه النبات - كليه الزراعه - جامعه الزقازيق

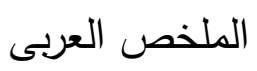

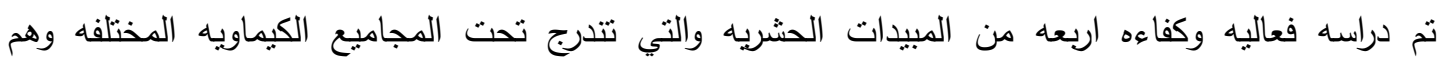

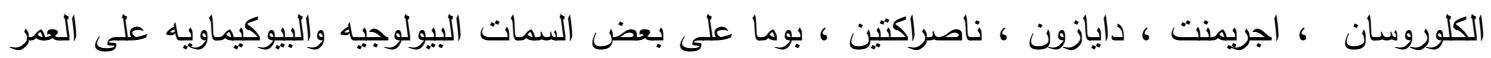

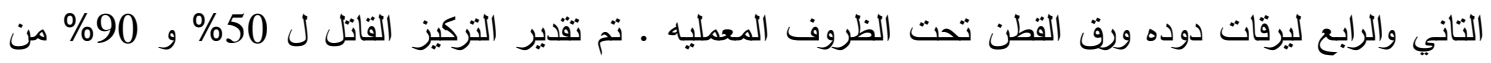

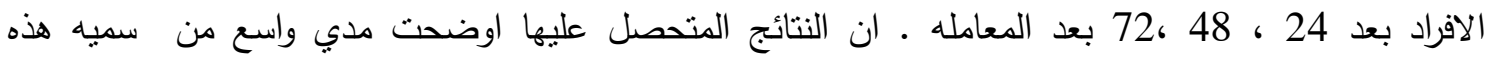

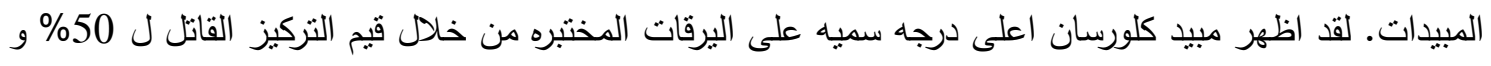

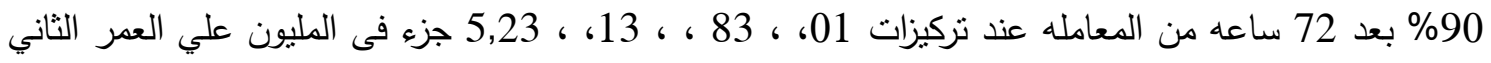

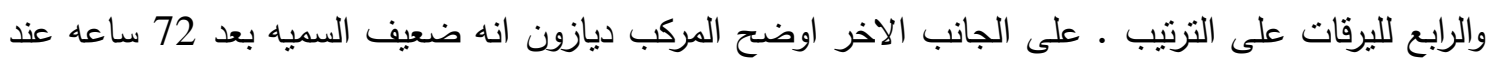

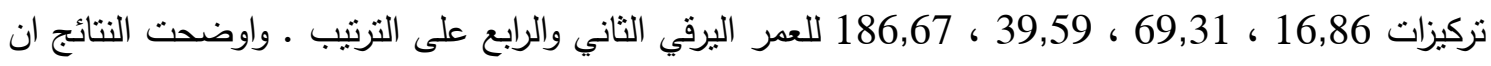

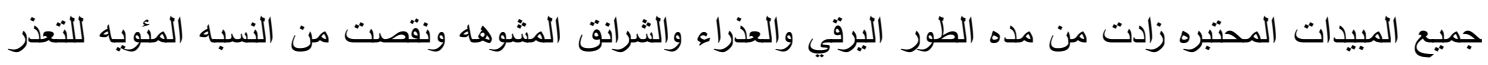
وخروج الحشرات الكامله مقارنه بالكنترول . 